\title{
Effects of Halopriming on Seed Germination and Seedling Emergence of Capsicum frutescens
}

\section{Dave Arthur R Robledo* \\ Da La Salle University, Philippines}

\section{Introduction}

Siling labuyo (Capsicum frutescens) is a small, commonly found chili pepper in the Philippines. This pepper is great to add spice, without altering the flavor of the dish because of its distinctive and complex taste. These plants are exposed to different abiotic factors including drought, salinity, high temperature, etc. which have adverse effects on plant growth and productivity. The soil salinity has become a critical problem worldwide among different environmental stresses due to their significant impacts on the physiology and performance of plants. Soil salinity is a significant factor that restricts Capsicum $f$. germination by affecting the establishment of crop plants. Germination is an important stage of planting and thus plays an important role in crop production. In cultivation of Capsicum f., low and slow seed germination and seedling emergence result in economic losses.

Seed priming has been developed as an important method for producing resistant plants against different stresses. It is a method of pre-germination treatment that increases seed quality and results in faster and more coordinated germination of seed. Halopriming is a simple and cheap seed priming method and is therefore considered suitable for farmers because of better synchronization of emergence and crops under different environmental conditions. In halopriming, the seeds are immersed in various salt solutions $\left(\mathrm{NaCl}\right.$ and $\mathrm{KNO}_{3}$ was used in this study) that facilitate the germination of seeds and subsequent seedling even under adverse environmental conditions.

\section{Objectives of the Study}

The aim of the study was to investigate the effects of halopriming on the osmotic tolerance potential of Capsicum frutescens on varied concentrations of $\mathrm{NaCl}$ and $\mathrm{KNO}_{3}$ as measured in their seed germination percentage and seedling emergence factors.

\section{Significance of the Study}

The findings of this study will be beneficial for the local chili farmers, market and agricultural community. In the production of agricultural and horticultural crops, seed quality plays an important role. Features such as variety, percentage of germination, purity, vigor, and appearance are important for farmers planting crops and homeowners planting lawns and gardens. The production of osmotic stress-resistant Capsicum $f$. seeds would also help in local food security. Creating local suppliers of various food items such as food spices in the sense of a global food shortage enhances food security in small rural communities. Communities investing in community farms help to protect farmland and create local food systems for the ongoing production of food.

\section{Limitation of the Study}

This study focused on the effects of halopriming on Capsicum $f$. under varied concentrations of two inorganic salts $\mathrm{NaCl}$ and $\mathrm{KNO}_{3}$ only. Some naturally occurring inorganic salts such as $\mathrm{CaCl}_{2}, \mathrm{KCl}, \mathrm{NaNO}_{3}, \mathrm{MnSO}_{4}, \mathrm{MgCl}_{2}$ etc. were not included in this study due to unavailability of resources and time constraints. This study also measured the seed germination rate and seedling emergence index of the Capsicum $f$. seeds to determine and to quantify the effects of halopriming. Other factors such as nutrient parameters, biochemical parameters and enzymatic activities were not included in this study due to unavailability of testing instruments.

\section{Review of Literature}

Soil salinity in tropical and coastal regions is one of the major concerns of the world. Studies show that $7 \%$ of the world's soils are salty and $3 \%$ are high in salt, with low rainfall, heavy evaporation and drainage of salt waters rising soil salinity [1]. Negative effects of high salt content on plants are caused by osmotic water retention and strong ionic influences on the protoplasm. Water is held in salt solutions osmotically, therefore, the concentration of increasing salt water is increasingly less accessible for plants. The soil salinity results to poor germination and seedling production. It is an enormous problem adversely affecting growth and development

*Corresponding author: Dave Arthur R Robledo, Da La Salle University, Philippines

Accepted: September 26, 2020

Published online: September 28, 2020

Citation: Robledo DAR (2020) Effects of Halopriming on Seed Germination and Seedling Emergence of Capsicum frutescens. J Bot Res 3(1):114-118 
of crop plants and results in to low agricultural production [2]. Salt and osmotic stresses are responsible for both inhibition or delayed seed germination and seedling establishment [3].

During the seed development on the parent plant, seeds of many species are dormant, and this germination resistance continues after the seeds are disseminated, and this' primary dormancy' is a crucial strategy to thrive under adverse conditions [4]. In the cultivation of Capsicum f., endosperm rupture is the major restriction which results to low and slow seed germination and seedling emergence. In these cases of endosperm-limited germination, it appears necessary to weaken the micropylar endosperm surrounding the radicle tip for radicle protrusion and is likely to involve hydrolysis of the cellwall by hydrolytic enzymes [5].

In general, seed quality is measured in many aspects, including genetic and physical purity, germination, seedling emergence, vigour, size harmonization, free seed disease and any other factors which can affect seed performance in the field. Quality of seed is therefore a collective term for seed conditions, including genetic and physical purity, viability, vigor, and the health of seeds. The value of seeds often leads to other attributes such as the specific chemical structure or tolerance of certain pathogens or insects.

Priming is a useful tool for improving the quality of seedlings [6]. Seed priming stimulates many of the metabolic processes involved in the early germination phases and it has been noted that seedlings from primed seeds appear faster, grow more vigorously and perform better under adverse conditions [7]. Seed priming has been successfully demonstrated to improve germination and emergence in seeds of many crops, particularly seeds of vegetables and small seeded grasses [8]. Duration of priming also plays an important role in strengthening the survival and vigour of seedlings under salinity conditions. Priming aims to shorten planting and emergence cycles and to protect seeds from biotic and abiotic factors during the crucial seedling process to synchronize emergence, resulting in uniform standing and improved return [9]. These priming methods which improves seed germination rate and seedling emergence include osmopriming [10]; solid matrix priming [11] hydropriming [12], halopriming [13] and hormonal priming [14].

In the process of halopriming, seeds are immersed in salt solutions that help to strengthen the seed in standardized environmental conditions and promote the cycle of seed germination. Seed priming has been described as treatment for pre-sowing in water or in an osmotic solution that permits seed to absorb water to go to the first stage of germination but prevents radical production via the seed coat. According to the study of Bray [15], primed seeds perform better in a wider range of temperatures and are less sensitive to oxygen deprivation [16] than unprimed ones. In the molecular basis, a number of genetic, biological and biochemical processes, including DNA replication and proteins, are implicated in the beneficial influence of priming [17]. According to Lee and Kim [18], priming also affects enzymatic activities by increasing enzyme activity and neutralizing the effects of seed ageing. Although the effects of priming treatments on germination of some seed crops has been studied, but relatively little information is available on the invigorating of Capsicum $f$. seed under salt stress.

\section{Methodology}

\section{Plant material}

Seeds of Capsicum $f$. were collected from the Municipal Agricultural Office of San Juan, Batangas, Philippines. The initial seed moisture was $8.17 \%$, (dry weight basis). The experiment was conducted at the Biology Laboratory of Saint Jude Catholic School, San Miguel, Manila during October 2019.

\section{Halopriming treatment}

Capsicum $f$. seeds were subjected to surface sterilization by soaking in $5 \%$ sodium hypochlorite solution for 5 minutes and dried on filter paper. These surface sterilized seeds were soaked in aerated solution of 10,25 and $50 \mathrm{ppm} \mathrm{NaCl}$ and $\mathrm{KNO}_{3}$ for 24 hours at $25^{\circ} \mathrm{C}$ with three replicates per salt concentration setup (unprimed seeds). The control setup was soaked in distilled water for 24 hours at $25^{\circ} \mathrm{C}$. After the priming treatment for specific period, seeds were washed with distilled water and dried at room temperature on filter paper in shade for 24 hours [19]. Seeds were then packed in resealable bags and stored in a refrigerator $4 \pm 2{ }^{\circ} \mathrm{C}$ for further use.

\section{Seed germination test}

Thirty seeds with each replicate per treatment were germinated in an incubator at $25{ }^{\circ} \mathrm{C}$ in a dark growth chamber with $45 \%$ relative humidity in $12 \mathrm{~cm}$ Petri dishes on two layers of Whatman No.1 filter paper and moistened with $4 \mathrm{ml}$ distilled water for seven days following Basra, et al. [20] procedure. Time to $50 \%$ germination (T50) was calculated according to the formulae of Coolbear, et al. [21]. Mean germination time (MGT) was calculated according to Ellis [22]. A seed is considered germinated when radicle length reached $2 \mathrm{ppm}$ or more [23]. Germinating seed were counted daily and terminated when no further germination occurred. Germination percentage (GP) was calculated as described by the Association of Official Seed Analysis [24] using the following formula:

$$
\mathrm{GP}=\frac{\text { Total Seeds Germinated }}{\text { Total number of seeds }} \times 100
$$

\section{Seedling emergence test}

According to Association of Official Seed Analysis [24], seed emergence is defined as the piercing of coleoptile of plumule through the soil to come up during seed germination forming the shoot and root system of the seedling. The haloprimed and control (unprimed) seeds were sown in plastic trays (25 in each) having moist soil, replicated thrice were placed in growth chamber [25] maintained at $25{ }^{\circ} \mathrm{C}$ under continuous fluorescent light for seven days. Emergence was recorded daily according to the seedling evaluation of the Handbook of Association of Official Seed Analysts [24].

Seedlings were harvested after two weeks and washed with deionized water after harvest. Afterwards they were separated into for the determination of their fresh and dry 
Citation: Robledo DAR (2020) Effects of Halopriming on Seed Germination and Seedling Emergence of Capsicum frutescens. J Bot Res 3(1):114-118

Table 1: Effects of Halopriming on the Germination of Capsicum. $f$ seeds.

\begin{tabular}{|l|l|l|l|l|l|l|}
\hline Halopriming & FGP (\%) & GI & MGT (days) & T50 & Root length $(\mathrm{cm})$ & Shoot length $(\mathrm{cm})$ \\
\hline Control & $63.45 \mathrm{c}$ & $7.8 \mathrm{e}$ & $7.31 \mathrm{~b}$ & $7.12 \mathrm{~b}$ & $4.30 \mathrm{c}$ & $4.67 \mathrm{c}$ \\
\hline $10 \mathrm{ppm} \mathrm{NaCl}$ & $76.22 \mathrm{~b}$ & $10.5 \mathrm{c}$ & $7.00 \mathrm{~b}$ & $6.52 \mathrm{c}$ & $5.20 \mathrm{~b}$ & $5.45 \mathrm{~b}$ \\
\hline $25 \mathrm{ppm} \mathrm{NaCl}$ & $68.45 \mathrm{~b}$ & $9.05 \mathrm{~d}$ & $7.15 \mathrm{~b}$ & $6.22 \mathrm{c}$ & $5.55 \mathrm{~b}$ & $5.32 \mathrm{~b}$ \\
\hline $50 \mathrm{ppm} \mathrm{NaCl}$ & $71.58 \mathrm{~b}$ & $9.54 \mathrm{~d}$ & $7.05 \mathrm{~b}$ & $6.38 \mathrm{c}$ & $5.32 \mathrm{~b}$ & $5.32 \mathrm{~b}$ \\
\hline $10 \mathrm{ppm} \mathrm{KNO}$ & $78.67 \mathrm{~b}$ & $12.23 \mathrm{c}$ & $5.93 \mathrm{c}$ & $6.13 \mathrm{c}$ & $5.63 \mathrm{~b}$ & $4.98 \mathrm{~b}$ \\
\hline $25 \mathrm{ppm} \mathrm{KNO}$ & $82.30 \mathrm{a}$ & $16.87 \mathrm{a}$ & $6.58 \mathrm{~b}$ & $4.89 \mathrm{a}$ & $6.23 \mathrm{a}$ & $6.46 \mathrm{a}$ \\
\hline $50 \mathrm{ppm} \mathrm{KNO}$ & $72.34 \mathrm{~b}$ & $14.05 \mathrm{~b}$ & $13.57 \mathrm{a}$ & $7.13 \mathrm{~b}$ & $5.50 \mathrm{~b}$ & $5.34 \mathrm{~b}$ \\
\hline
\end{tabular}

Figures not sharing the same letters in a column differ significantly at $p<0.05$; FGP: Final Germination Percentage; GI: Germination Index; MGT: Mean Germination Time; T50: time take to $50 \%$ of germination.

Table 2: Effects of Halopriming on the Seedling Emergence of Capsicum. $f$ seeds.

\begin{tabular}{|l|l|l|l|l|}
\hline Halopriming & Radicle Length $(\mathrm{cm})$ & Plumule Length $(\mathrm{cm})$ & Fresh weight $(\mathrm{g})$ & Dry weight $(\mathrm{g})$ \\
\hline Control & $1.6 \mathrm{c}$ & $4.67 \mathrm{c}$ & $22.90 \mathrm{e}$ & $6.68 \mathrm{~d}$ \\
\hline $10 \mathrm{ppm} \mathrm{NaCl}$ & $1.84 \mathrm{~b}$ & $4.57 \mathrm{c}$ & $25.20 \mathrm{~b}$ & $7.08 \mathrm{c}$ \\
\hline $25 \mathrm{ppm} \mathrm{NaCl}$ & $1.97 \mathrm{~b}$ & $4.51 \mathrm{c}$ & $24.80 \mathrm{c}$ & $8.00 \mathrm{~b}$ \\
\hline $50 \mathrm{ppm} \mathrm{NaCl}$ & $1.34 \mathrm{~d}$ & $4.15 \mathrm{~d}$ & $23.56 \mathrm{~d}$ & $6.70 \mathrm{~d}$ \\
\hline $10 \mathrm{ppm} \mathrm{KNO}$ & $2.02 \mathrm{~b}$ & $4.75 \mathrm{ab}$ & $25.00 \mathrm{~b}$ & $7.00 \mathrm{c}$ \\
\hline $25 \mathrm{ppm} \mathrm{KNO}_{3}$ & $2.33 \mathrm{a}$ & $4.89 \mathrm{a}$ & $28.96 \mathrm{a}$ & $8.53 \mathrm{a}$ \\
\hline $50 \mathrm{ppm} \mathrm{KNO}_{3}$ & $1.89 \mathrm{~b}$ & $4.80 \mathrm{~b}$ & $24.06 \mathrm{c}$ & $7.26 \mathrm{c}$ \\
\hline
\end{tabular}

Figures not sharing the same letters in a column differ significantly at $p<0.05$

weight and measurement of radicle and plumule length. Dry weight was determined after oven drying the samples at 65 ${ }^{\circ} \mathrm{C}$ for 48 hours in oven.

\section{Statistical analysis}

The data recorded were gathered for statistical analyzes using software SPSS version 30 to determine the significance of variance $(p<0.05)$. A multiple-range Duncan test was used to compare differences between treatment means [26].

\section{Results}

\section{Seed dermination}

The germination potential of Capsicum $f$. seeds has been considerably influenced by halopriming treatments with p-value of less than 0.05 (Table 1). Most of the priming treatments resulted in lower T50 and MGT and higher GI, FGP, shoot and root lengths as compared to unprimed seeds (control). Significant germination was achieved in seeds primed with 25 ppm $\mathrm{KNO}_{3}$ as indicated by lower MGT, T50 and higher FGP, GI and radicle length than primed or non-treated seeds. It was also shown in the Table 1 that priming with low concentration salt (10 ppm NaCl and $10 \mathrm{ppm} \mathrm{KNO}_{3}$ ) also enhanced germination potential of Capsicum $f$. seeds by decreasing MGT and increasing FGP and GI. It is notable that priming with higher concentration of $\mathrm{KNO}_{3}(25$ and $50 \mathrm{ppm}$ ) failed to improve MGT and T50 of Capsicum $f$. seeds.

\section{Seedling emergence}

There was a significant $(p<0.05)$ effect of halopriming treatments on radicle and plumule lengths on the seedling emergence of Capsicum $f$. (Table 2). Overall, priming with various concentrations of $\mathrm{KNO}_{3}$ was more effective than $\mathrm{NaCl}$.

Seed priming with 25 ppm $\mathrm{KNO}_{3}$ gave higher values of radicle and plumule length and fresh and dry weights as compared with other primed or control seeds. Although priming with various concentrations of $\mathrm{NaCl}$ salt failed to improve seedling emergence of Capsicum $f$; however, lowest radicle and plumule lengths and biomass was recorded in seeds primed with $50 \mathrm{ppm} \mathrm{NaCl}$.

\section{Discussion}

After conducting the experiment, it is noticeable that the earlier germination and emergence was observed in seeds primed with $25 \mathrm{ppm} \mathrm{KNO}_{3}$ as proven by lesser mean germination time, higher final germination, shoot length, seedling fresh and dry weight A significant time reduction to $50 \%$ germination can be attributed to the early breakdown of the reserve. This event is similar to the findings of Hisashi, hat seed reserves might breakdown early due to possible early activation of cell wall degrading proteins. This result coincides with the study of Sarihan, et al. as shown in Table 1. Roberts [23] reported a substantial presumptive treatment of $\mathrm{KNO}_{3}(50$ and $150 \mathrm{mM}$ ) endives, possibly through a pentoidal shift in the respiratory metabolism into the pathway of the pentose phosphate, via oxidized forms of nitrogen.

$\mathrm{NaCl}$ halopriming treatments did not improve the germination and seedling emergence compared to seed treatment with $\mathrm{KNO}_{3}$; it may be that $\mathrm{NaCl}$ treated Capsicum $f$. seeds took 
up more $\mathrm{Na}^{+}$and/or $\mathrm{Cl}^{-}$from the salt solution, contributing to the toxic effect indicated by Bradford [8]. The findings for the radicle and plumule and fresh and dry weights agree with the results of Ashraf [27] who reported that fresh and dry weights of seedlings from haloprimed seeds were significantly higher, as compared to other unprimed seeds.

Halopriming with $\mathrm{NaCl}$ could stimulate the effect related to toxic effect as a result of salt stress. At the high concentration of $\mathrm{NaCl}$ treatment (50 ppm), the toxicity would be amplified, and the stimulating effect would be nullified as shown in Table 2. Halopriming with $\mathrm{NaCl}$ might pose toxicity problems as ions accumulate in tissues as reported in various vegetable species [28]. The significant increase in the length of shoot was recorded in $\mathrm{KNO}_{3}$ treated seeds as compared to control and remaining priming treatments, this event might be the result of higher embryo cell wall extensibility parallel to the study of Demir and Oztokat [29].

\section{Conclusion}

Based from the results of this study, it can be concluded that germination and seedling emergence may be enhanced by halopriming treatments in $\mathrm{KNO}_{3}$. $\mathrm{NaCl}$ halopriming treatments did not improve the germination and seedling emergence compared to seed treatment with $\mathrm{KNO}_{3}$. It can also be concluded that halopriming with $\mathrm{NaCl}$ could stimulate the effect related to toxic effect as a result of salt stress. Overall, halopriming with $25 \mathrm{mM} \mathrm{KNO}_{3}$ was more effective than all other halopriming treatments.

\section{Recommendations}

A thorough study related to the physiological and yield related attributes may be considered like other factors such as nutrient parameters, biochemical parameters and enzymatic activities. The primed seeds of other Capsicum species may be considered for detailed physiological and yield related attributes. Some naturally occurring inorganic salts such as $\mathrm{CaCl}_{2}, \mathrm{KCl}, \mathrm{NaNO}_{3}, \mathrm{MnSO}_{4}, \mathrm{MgCl}_{2}$ etc. could also be subjected to future priming research.

\section{References}

1. Teimouri JM, Powell AA (2009) Short term aerated hydration for the improved of seed quality on Brassica oleracea. Seed Sci Res 2: 41-49.

2. Garg S, MA Gupta (2011) Germination of a halophytic grass Aehropus lagopoides. J Ann Bot 87: 3119-3329.

3. Almansouri P, AR Muthiah (2007) Effect of $\mathrm{NaCl}$ salinity stress on seed germination and seedling growth of chick pea (Cicer arietinum L.). Legume Res 30: 141-144.

4. Osborne HC (1981) The effects of osmoconditioning on the germination, emergence and early plant growth of cucumber under saline conditions. Hort Sci 57: 233-240.

5. Bewley JD (1997) Breaking down the walls - a role for endo- $\beta$ manganese in release from seed dormancy. Trends in Plant Sci 2: 464-469.

6. Mavi HR, Ali AS, Farzad SZ, et al. (2011) Study of different priming treatments on germination traits of Soybean seed lots. Not Sci Biol 3: 101-108.
7. Chavan EA, MC Bolarin, F Perez-Alfoce, et al. (2014) Effect of $\mathrm{NaCl}$ priming on increased salt tolerance in tomato. J Hort Sci 66: 621-628.

8. Bradford KJ (1995) Water relation in seed germination. In: J Kigel, G Galili, Seed development and germination Marcel Dakker, NY, 351-396.

9. Khan AA (1992) Pre-plant physiological seed conditioning. In: J Janick, Horticultural Reviews, John Willey and Sons, NY, 131-181.

10. Hardegree SP, Van Vactor SS (2000) Germination and emergence of primed grass seeds under field and simulated-field temperature regimes. Ann Bot 85: 379-390.

11. Golezani A (2010) Water uptake and germination of leguminous seeds in soils of changing matrix and osmotic water potential. J Exp Bot 28: 977-985.

12. Afzal I, SMA Basra, N Ahmad (2002) Hormonal priming induces salt tolerance in wheat through enhanced antioxidant defense system. Cereal Res Common 39: 334-342.

13. Afzal I, Basra SMA, Ahmad N, et al. (2009) Effect of priming and growth regulator treatment on emergence and seedling growth of hybrid maize (Zea mays). Int J Agric Biol 4: 303-306.

14. Afzal I, Basra SMA, Farooq M, et al. (2006) Alleviation of salinity stress in spring wheat by hormonal priming with $A B A$, salicylic acid and ascorbic acid. Int J Agric Biol 8: 23-28.

15. Bray CM (1995) Biochemical process during the osmopriming of seeds. In: Kigel J, G Galili, Seed Development and Germination. Marcel Dekker, Inc, New York, 767-789.

16. Corbineau F, Black M, Come D (1993) Induction of thermidoreans in Avena sativa seeds. Seed Sci Res 3: 111-117.

17. Bewely JD, Black M (1982) Physiology and biochemistry of seeds in relation to germination, Vol 2. Viability, dormancy, and environmental control. Springer-Verlag, Berlin.

18. Lee SS, Kim JH (2000) Total sugars, $\alpha$-amylase activity and germination after priming of normal and aged rice seeds. Korean $\mathrm{J}$ Crop Sci 45: 108-111.

19. Bennett MA, Waters L (1987) Seed hydration treatments for improved sweet corn germination and stand establishment. J Amer Soc Hort Sci 112: 45-49.

20. Basra SMA, M Farooq, R Tabassum (2005) Physiological and biochemical aspects of seed vigour enhancement treatments in fine rice (Oryza sativa L.). Seed Sci Technol 33: 623-628.

21. Coolbear P, Francis A, Grierson D (1984) The effect of low temperature pre-sowing treatment under the germination performance and membrane integrity of artificially aged tomato seeds. J Exp Bot 35: 1609-1617.

22. Ellis RA, Roberts EH (1981) The quantification of ageing and survival in orthodox seeds. Seed Sci Technol 9: 373-409.

23. Robert SE, Smith RD (1977) Dormancy and the pentose phosphate pathway. In: Khan A, The physiology and biochemistry of seed dormancy and germination. North-Holland Publishing Co, Amsterdam, 385-411.

24. Association of Official Seed Analysis (1986) Seed vigor testing handbook. Contribution no. 32 to the handbook on seed testing. Association of official seed analysis. Springfield, IL.

25. Vindon NG (1999) Effect of pre-sowing treatment on seed germination and seedling vigour in endive and chicory. Journal of Vegetable Science 68: 125-132. 
26. Steel RGD, Torrie JH, Dickey DA (1997) Principles and procedures of statistics: A biometric approach. ( $3^{\text {rd }}$ edn), McGraw Hill Book Co Inc, New York.

27. Ashraf M, Rauf $H$ (2001) Inducing salt tolerance in maize (Zea mays $L$.) through seed priming with chloride salts: Growth and ion transport at early growth stages. Acta Physiol Plant 23: 407417.
28. Brocklehurst PA, Dearman J (1984) A comparison of different chemicals for osmotic treatment of vegetable seed. Annu Appl Biol 105: 391-398.

29. Demir I, Oztokat C (2003) Effect of salt priming on germination and seedling growth at low temperatures in water melon seeds during development. Seed Sci Technol 31: 765-770. 